Chirurgia (2021) 116: 568-572

No. 5, September - October

Copyright@ Celsius

http://dx.doi.org/10.21614/chirurgia.116.5.568

\title{
Inguinal Hernia - Is There Any Room Left for Classical Procedures?
}

\author{
Horia Doran', Florin-Teodor Bobircăa ${ }^{1 *}$, Dan Dumitrescu ${ }^{2}$, Mihai Pecie ${ }^{2}$, Traian Pătrașcu ${ }^{1}$ \\ "'Carol Davila" University of Medicine and Pharmacy, Bucharest, Romania \\ 2"Dr. I. Cantacuzino" Clinical Hospital, Bucharest, Romania
}

*Corresponding author:

Florin-Teodor Bobircă, MD, PhD

"Carol Davila" University of Medicine

and Pharmacy, Bucharest, Romania

E-mail:dr.bobirca@gmail.com

\section{Rezumat}

Herniile inghinale - mai este loc pentru tehnicile clasice?

Introducere: Actualmente, rezolvarea chirurgicală a herniilor inghinale este obținută de regulă prin abord minim invaziv (TAPP sau TEP), cu avantajele sale bine-cunoscute. $\mathrm{Cu}$ toate acestea, tehnica Lichtenstein îşi menține indicațiile sale particulare. Metodă: Am analizat retrospectiv 256 pacienți consecutivi, cărora li s-a efectuat operația Lichtenstein într-un interval de 5 ani (2015-2019), în Clinica de chirurgie a Spitalului Clinic "Dr. I. Cantacuzino". Marea majoritate a lor - 180 (74\%) aveau 60 de ani sau mai mult, dintre care $105(41 \%)$ - peste 70 de ani. Am notat prezența unor afecțiuni cardio-vasculare severe, a diabetului zaharat sau a altor co-morbidități semnificative la 128 de pacienți $(50 \%)$.

Rezultate: 240 pacienți au evoluat favorabil, 12 au avut complicații locale, iar la 4 au apărut evenimente cardiace postoperatorii. 1 pacient a decedat în urma unui infarct miocardic masiv.

Concluzii: Tratamentul chirurgical al herniilor inghinale trebuie să fie potrivit vârstei şi status-ului biologic al pacienților; serviciile de chirurgie generală ar trebui să fie în măsură să ofere atât posibilitatea unui abord laparoscopic, cât şi a unuia clasic.

Cuvinte-cheie: hernie inghinală, tehnica Lichtenstein
Abstract

Background: Nowadays, the repair of inguinal hernias is mostly 
achieved through a minimally invasive approach (TAPP or TEP) which has well-known advantages. However, the Lichtenstein mesh technique still has some particular indications.

Methods:We reviewed 256 consecutive patients who underwent a Lichtenstein procedure during 5 years (2015-2019) in the Department of General Surgery of "Dr. I. Cantacuzino" Clinical Hospital. The vast majority of them - $180(74 \%)$ were 60 or older and $105(41 \%)$ were over 70 . Severe cardiovascular diseases, diabetes mellitus and other significant co-morbidities were recorded in 128 patients (50\%).

Results: 240 patients had a favorable evolution, 12 experienced local complications, while in 4 we recorded severe cardiac post-operative events. 1 patient died due to a massive myocardial infarction. Conclusions: The surgical treatment of inguinal hernias should be adapted to the age and biological status of the patient; surgical departments must be able to provide both a laparoscopic and an open-surgery approach.

Key words: inguinal hernia, Lichtenstein technique

\section{Introduction}

There is a large consensus among surgeons specializing in abdominal wall reconstruction that mesh repair - performed either through a laparoscopic or an open technique - is "the gold standard". The general rule regarding the approach is that an anterior repair is indicated for recurrent hernia after a posterior procedure, while in recurrences occurring after an anterior approach, a posterior repair offers the advantages of a normal anatomy and should therefore be preferred (1). Our study did not intend to compare the indications and advantages of laparoscopic and open surgery and to plead the cause of one or another; this dilemma has been clarified many years ago. Our objective was to identify the specific situations and criteria which may indicate a classical surgical treatment of inguinal hernias; we also tried to establish if the teaching/learning of "old" techniques by young surgeons is still useful or necessary.

\section{Material and Methods}

We reviewed 256 consecutive patients who underwent a Lichtenstein operation for inguinal hernia over a time span of 5 years (2015-2019) in the Surgical Clinic of "Dr. I. Cantacuzino" Clinical Hospital.
First of all, it may be surprising that the number of procedures per year (around 50) did not significantly change during this period (Fig. 1) whereas the number of laparoscopic interventions has significantly increased, following the general trend of minimally invasive surgery. Therefore, we may surmise that in certain patients the indication for a classical method remains well defined.

As expected, our lot included mostly male patients - $243(95 \%)$. We encountered a high prevalence among the $7^{\text {th }}$ decade - 85 cases $(33 \%)$, and $8^{\text {th }}$ decade -78 patients $(30.4 \%)$. We also identified 27 patients (10.5\%) who were over 80 . Overall, 190 of the 256 operations (74\%) were performed in patients over 60 (Fig. 2).

As 3 in 4 patients were in their 60 s or 70 s, significant comorbidities were almost the rule: severe cardiac and vascular diseases (stroke,

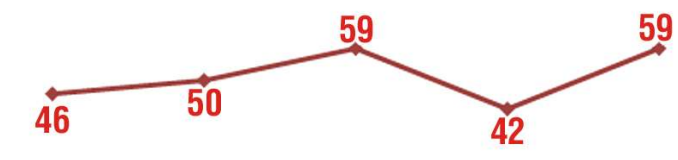

\section{$\begin{array}{lllll}2015 & 2016 & 2017 & 2018 & 2019\end{array}$}

Figure 1. Number of procedures/year 


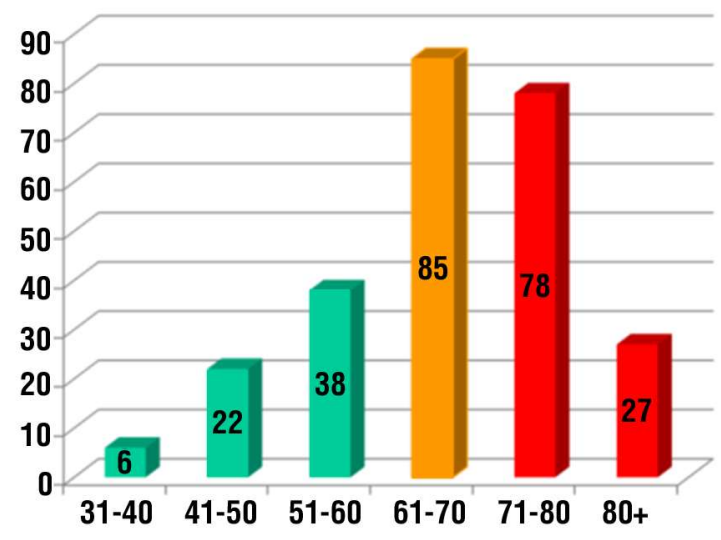

Figure 2. Age groups

heart failure, atrial fibrillation, aortocoronary bypass, coronary stent, pace-maker, myocardial infarction) - in 64 patients $(25 \%)$; diabetes mellitus - in 34 (15\%); cirrhosis - in 14 , operated neoplasma - in 10, respiratory diseases (asthma, chronic bronchitis) - in 8. Many of them had several associated conditions. The level of thromboembolism risk was estimated as moderate (minor surgery in patients with additional risk factors) and low-molecular-weight heparin prophylaxis was therefore indicated. Also, prophylactic antibiotics were considered necessary, as the technique requires prosthesis placement.

Particular anatomical forms consisted of: 11 cases of recurrent hernia; 8 - giant hernia; 8 - double (indirect and direct) hernia, on the same part; 5 - bilateral hernia, 4 - associated hydrocele.

A very interesting finding was the number of procedures per surgeon (Fig. 3). Although 11 doctors operated these patients, $155(60.5 \%)$ of all the operations were performed by only 3 of them; a personal preference for Lichtenstein technique cannot be therefore denied.

\section{Results}

240 patients $(93.7 \%)$ had a favorable evolution. 12 experienced minor surgical complications: 7 of them developed local hematoma (probably due to high blood pressure) and required a reintervention. In 5 other patients, seroma of the scrotum occurred and antiinflammatory treatment led to its resolution.

There were 4 cases of serious post-operative cardiac events: severe arrhythmia in 3 patients, which had a favorable evolution after medical treatment and 1 case of massive myocardial infarction, which ended in exitus.

We were not able to identify any cases of recurrence or mesh rejection after these above-mentioned procedures, although all the patients were recalled and more than 200 of them came back for a post-operative check (after 1 and 6 months). Our experience shows that a significant proportion of recurrent hernias are admitted in the same department and even by the same surgeon, so it is reasonable to presume that the recurrence rate was indeed very low. The median post-operative stay was 4.2 days.

\section{Discussions}

Far from being considered an outlier of surgical activity, the repair of abdominal wall defects comprises a significant part of our experience. It is estimated that during their lifetime, one third of all male patients are diagnosed with an inguinal hernia (2). A large study of almost 45,000 cases from the US Armed Forces, found that the overall incidence of inguinal hernia diagnoses during 10 years (2010-2019) was 34.3 per 10,000 personyears (3). Half of these patients were operated, $54.6 \%$ of them using an open procedure and



Figure 3. Number of procedures per surgeon 
the rest of $45.4 \%$ - a laparoscopic one.

The concept of tension-free repair made the most substantial difference in terms of lower recurrence rates and post-operative pain (4). The best-known operation was Lichtenstein hernioplasty, which began in 1974 (5) and soon became the gold standard of hernia repair for the American College of Surgeons. Its worldwide reported recurrence and complication rates are less than $1 \%(6,7)$. It has the added advantage of not being expensive or difficult to learn; the number of operations required to master the technique is around 40 hernia repairs (8).

Afterwards, minimally invasive procedures became an essential part of modern surgery; nowadays, repair of inguinal hernias mainly includes TAPP and TEP techniques. However, international guidelines for hernia management state that, while mesh repair is recommended as the first choice, one standard repair operation for all hernias does not exist. Therefore, there is still room for both open and laparoendoscopic repair techniques in current surgical practice. Ideally, surgical departments should be able to provide both of them (1). We should keep in mind that in laparoscopic hernia repair the learning curve was completed after 75 cases - longer than in open surgery (9).

In our study, the number of classical procedures did not significantly change during these 5 years (2015-2019); meanwhile, TAPP and TEP techniques have been widely learned and performed. The explanation lies mainly in the demographic and pathological characteristics of our patients: $74 \%$ of all patients were in their $60 \mathrm{~s} ; 41 \%$ were in their $70 \mathrm{~s}$. Most of them had cardiac, respiratory, metabolic and/or other diseases, which made general anesthesia and abdominal inflation undesirable. Significant negative effects on heart rate values during general anesthesia and after induction of pneumoperitoneum are documented (10) in medical literature. On the other hand, such events do not occur after spinal anesthesia, which was preferred in almost all our cases (11). Cardiac post-operative complications, among which 3 out of 4 were successfully managed with a conservative treatment, were modest in terms of incidence and severity, if compared to the high incidence of cardiovascular comorbidities.

However, spinal anesthesia induces hypotension $(12,13)$, which may well have been the cause of post-operative hematoma once the blood pressure became normal again. Overall, the complications of the procedures were, as expected, minor and rare. The anterior approach is safer and visceral lesions are almost entirely absent, comparative to laparoendoscopic techniques (14).

The personal preference of the surgeon cannot be denied - 155 of the 256 procedures $(60.5 \%)$ were performed by 3 of the 11 surgeons in the department. Although there are data in literature which found that the majority of the respondents who preferred open hernia repair had little experience in laparoscopy (and therefore Lichtenstein was a better known technique)(15), in our study the 3 above-mentioned surgeons had vast experience with and a high appreciation of minimally invasive methods; they preferred an open method due to their patients' particularities. Meanwhile, in the real-life conditions of our medical system, the necessary devices for laparoscopic procedures are quite expensive and not always available. The impact of financial circumstances on the therapeutic decision is difficult to measure.

The recurrence rate following Lichtenstein operation is less than 1\%. Even more important, several studies and meta-analyses which reported thousands of cases have proved that there is no difference in recurrence rates between laparoscopic and open hernia repair $(16,17)$. Nevertheless, it seems that in female patients laparoscopic repair has lower reoperation rates and fewer recurrences than open techniques (18).

To conclude, a network meta-analysis with 5594 patients, 1228 of which underwent a TAPP procedure, 2067 - TEP and 2299 Lichtenstein found that there were no significant differences regarding: rate of recurrence, formation of seroma and hematoma, chronic pain and length of post-operative hospital stay. The procedures took more time when 
using TAPP and TEP techniques than the Lichtenstein repair, while the laparoscopic approach was associated with a shorter recovery time (19).

Classical and minimally invasive procedures have their own specific indications; surgeons should acquire the necessary skills and training in order to be able to perform both. It has also been suggested that young surgeons could attend a clinical fellowship, in order to obtain an additional qualification as an abdominal wall specialist under supervision (20).

\section{Conclusion}

Almost half a century after it was first presented by Irving Lichtenstein, his mesh repair procedure for inguinal hernias is still widely performed. In our study, the main indications in its favor were the age over 60 (and even more so over 70) and cardiovascular comorbidities, which made general anesthesia and abdominal inflation undesirable. Overall, this technique has the same results as laparoendoscopic ones in terms of rate of recurrence, chronic pain and length of postoperative stay; it has the advantages of reduced operation time and a shorter learning curve. The laparoscopic approach is associated to a more rapid recovery and therefore it should be the first choice in young, active patients.

\section{Funding}

The authors did not receive any funding for this work.

\section{Conflict of Interests}

The authors have no conflict of interests to disclose.

\section{Ethics Approval}

The study has been performed by following the ethical norms of scientific research and the principles of confidentiality.

\section{References}

1. HerniaSurge Group. International guidelines for groin hernia management. Hernia. 2018;22(1):1-165.

2. Berndsen MR, Gudbjartsson T, Berndsen FH. Inguinal hernia - review. Laeknabladid. 2019;105(9):385-391.

3. Stahlman S, Fan M. Incidence of inguinal hernia and repair procedures and rate of subsequent pain diagnoses, active component service members, U.S. Armed Forces, 2010-2019. MSMR. 2020;27(9):11-16.

4. Bolocan A, Ion D, Constantinescu S, Luca A-D, Păduraru DN. Randomised Trial Comparing Polypropylene Mesh and Polyvinydilene Fluoride Mesh in the Surgery. Materiale Plastice. 2012;49(3):209-211.

5. Lichtenstein IL, Shore JM. Simplified repair of femoral and recurrent inguinal hernias by a "plug" technic. Am J Surg. 1974;128(3):439-44.

6. Amid PK. Lichtenstein tension-free hernioplasty: its inception, evolution, and principles. Hernia. 2004;8(1):1-7.

7. Lydeking L, Johansen N, Oehlenschläger J, Bay-Nielsen M, Bisgaard T. Re-recurrence and pain 12 years after laparoscopic transabdominal preperitoneal (TAPP) or Lichtenstein's repair for a recurrent inguinal hernia: a multi-centre single-blinded randomised clinical trial. Hernia. 2020; 24(4):787-792.

8. Merola G, Cavallaro G, Iorio 0, Frascio M, Pontecorvi E, Corcione F, et al. Learning curve in open inguinal hernia repair: a quality improvement multicentre study about Lichtenstein technique. Hernia. 2020;24(3):651-659. Epub 2019 Nov 22.

9. Kuge H, Yokoo T, Uchida H, Yamaoka K, Yoshikawa S. Learning curve for laparoscopic transabdominal preperitoneal repair: A single-surgeon experience of consecutive 105 procedures. Asian J Endosc Surg. 2020; 13(2):205-210. Epub 2019 Jul 7

10. Sarakatsianou C, Georgopoulou S, Tzovaras G, Perivoliotis K, Papadonta ME, Baloyiannis I. Hemodynamic effects of anesthesia type in patients undergoing laparoscopic transabdominal preperitoneal inguinal hernia repair under spinal vs general anesthesia. Hernia. 2019;23(2):287-298.

11. Olsen JHH, Öberg S, Andresen K, Klausen TW, Rosenberg J. Network metaanalysis of urinary retention and mortality after Lichtenstein repair of inguinal hernia under local, regional or general anaesthesia. Br J Surg. 2020;107(2):e91-e101. Epub 2019 0ct 1.

12. Wong CA. Spinal anesthesia-induced hypotension: is it more than just a pesky nuisance? Am J Obstet Gynecol. 2020;223(5):621-623.

13. Bütner B, Mansur A, Bauer M, Hinz J, Bergmann I. Unilateral spinal anesthesia: Literature review and recommendations. Anaesthesist. 2016; 65(11):847-865. German.

14. Reinpold W, Chen D. Die evidenzbasierte Lichtenstein-Technik Evidencebased Lichtenstein technique. Chirurg. 2017;88(4):296-302. German.

15. Kulaçoglu HI, Ozmen MM, Oruç MT, Koç M, Kama NA. Laparoscopic herniorrhaphy: preference rate among surgeons in Ankara, Turkey. East Afr Med J. 2001;78(4):216-9.

16. Bullen NL, Massey LH, Antoniou SA, Smart NJ, Fortelny RH. Open versus laparoscopic mesh repair of primary unilateral uncomplicated inguinal hernia: a systematic review with meta-analysis and trial sequential analysis. Hernia. 2019;23(3):461-472.

17. Scheuermann U, Niebisch S, Lyros O, Jansen-Winkeln B, Gockel I. Transabdominal Preperitoneal (TAPP) versus Lichtenstein operation for primary inguinal hernia repair - A systematic review and meta-analysis of randomized controlled trials. BMC Surg. 2017;17(1):55.

18. Schmidt L, Öberg S, Andresen K, Rosenberg J. Laparoscopic repair is superior to open techniques when treating primary groin hernias in women: a nationwide register-based cohort study. Surg Endosc. 2019;33(1):71-78. Epub 2018 Jun 15.

19. Lyu Y, Cheng Y, Wang B, Du W, Xu Y. Comparison of endoscopic surgery and Lichtenstein repair for treatment of inguinal hernias: A network metaanalysis. Medicine (Baltimore). 2020;99(6):e19134.

20. Köckerling F, Sheen AJ, Berrevoet F, Campanelli G, Cuccurullo D, Fortelny $\mathrm{R}$, et al. The reality of general surgery training and increased complexity of abdominal wall hernia surgery. Hernia. 2019;23(6):1081-1091. 